\title{
FINANCING VENTURE CAPITAL INVESTMENTS IN A COVID-19 LANDSCAPE
}

\author{
FINANSOWANIE INWESTYCJI Z VENTURE CAPITAL \\ W WARUNKACH COVID-19
}

https://doi.org/10.34739/zn.2020.54.03

\author{
Marcin Wilk \\ Poland, WSB University, Faculty of Management and Quality Sciences \\ m.wilk@sfr-slaskie.pl, ORCID: 0000-0003-2661-8979
}

JEL Classification Codes: G2, G24

\begin{abstract}
This article attempts to identify factors negatively affecting economic growth in developing regions and to answer the question of what aid is effective in the form of individualized investment activities that correspond to selected development problems in startups and small enterprises. The use and implementation of capital instruments based on commercial investment standards allows to increase the efficiency of managing financial intervention processes in times of crisis, as well as strengthening local enterprises by improving their capital position. In addition, it enables the implementation of valuable products and services based on new technologies. Key words: Venture capital, equity gap, intervention support, SME, startup, enterprise financing, crisis, COVID-19

Streszczenie: W artykule podjęta została próba zidentyfikowania czynników wpływających negatywnie na wzrost gospodarczy w rozwijających się regionach oraz udzielenie odpowiedzi na pytanie, jaka pomoc jest skuteczna w formie zindywidualizowanych działań inwestycyjnych, odpowiadających wybranym problemom rozwojowym w startupach i małych przedsiębiorstwach. Wykorzystanie i wdrożenie instrumentów kapitałowych opartych na komercyjnych standardach inwestycyjnych pozwala zwiększyć efektywność zarządzania procesami interwencji finansowych w dobie kryzysu, a także wzmacnia lokalne przedsiębiorstwa, poprawiając ich pozycję kapitałową. Ponadto umożliwia wdrożenie wartościowych produktów i usług opartych na nowych technologiach. Słowa kluczowe: Venture capital, luka kapitałowa, wsparcie interwencyjne, MŚP, startup, finansowanie przedsiębiorstw, kryzys, COVID-19
\end{abstract}

\section{Introduction}

There is no doubt that the financial crisis triggered by the COVID-19 pandemic represents a breakdown of the global economy. It has already led to a partial paralysis of the global financial system, a collapse in capital markets and a global recession, the depth of which is unknown. The protracted state of the COVID-19 pandemic threat turned out to be a very real determinant having a negative impact on the functioning of national economies almost all over the globe.

This situation has also affected the Polish economy. Its effects have been felt in almost every aspect of the economy, pertaining to consumers, entrepreneurs and employers. Contrary to previous crises which were caused by a demand shock, now we are dealing with both a demand and supply shock. The supply shock has been influenced by the closure of some production plants and the collapse of parts of the supply chain. In terms of the demand shock, shops are closed for the period of quarantine. The state of the epidemiological threat has caused a decrease in demand for both consumer and capital goods. This has contributed to a reduction in turnover in the economy (Derkacz, 2020, p. 2). Long-term lockdowns and the closures of many sectors of the economy, as well as broken supply chains on a global scale, have affected the supplies of semifinished products and components for production, resulted in a loss of liquidity for enterprises, reductions in orders and, consequently, a wave of employee layoffs. There has been a commensurate decrease in the disposable income of households and a negative impact on the liquidity and profitability of economic activities. 
The effects of the epidemiological threat of the COVID-19 virus have put modern entrepreneurs in a rather uncomfortable situation related to the difficulty of running a business in a situation of falling demand for products and services. Many of them have been forced to opt for significant cost reduction. Meanwhile, costs, especially labor costs, should not be reduced for reasons resulting from a crisis situation. An indirect effect of the decline in profitability of economic activity has also been slower consumption and tightening liquidity on the part of entrepreneurs.

There is also no doubt that the economy will change significantly after the epidemic. Companies are starting to reorganize, consumers are looking for alternative consumption channels and the economy is taking a new shape. For this to happen, it will be necessary to flexibly adjust the sources of financing to the needs of enterprises. It will also be necessary to launch intervention measures that will allow entrepreneurs to survive the most difficult period and restore lost liquidity. In the longer term, companies will have to look for capital to finance investments in innovative solutions.

\section{Sources of financing for enterprises}

Business entities have various forms of financing at their disposal. In theory and practice, financing is systematically applied using the following criteria:

- time of capital commitment,

- sources of capital acquisition,

- ownership and legal position of the capital provider.
The breakdown of forms of financing related to the sources of capital acquisition is divided according to the criterion of ownership and legal position of the entity contributing the capital, corresponding to the financial reporting standards (balance sheet liabilities).

According to this division, the following are distinguished:

- equity - including the equivalent of economic resources left at the disposal of the enterprise owners,

- external capital - including the equivalent of funds lent to the company by external entities, i.e. creditors. Foreign capital is entrusted to the company for a strictly defined period of time, after which they are returned.

In turn, broken down by the criterion of sources of capital acquisition, the following are distinguished:

- internal financing - the source of capital is the cash surplus obtained through business activity (a surplus of cash inflows over expenses),

- external financing - the source of capital is a financial surplus or tangible capital from outside the company, lent to an economic entity for a fixed or indefinite period. Some authors also include funds from the owners as external funds from the owners, such as "new" capital from existing owners (e.g. owners' subsidies) or capital from new owners (e.g. new share issues).

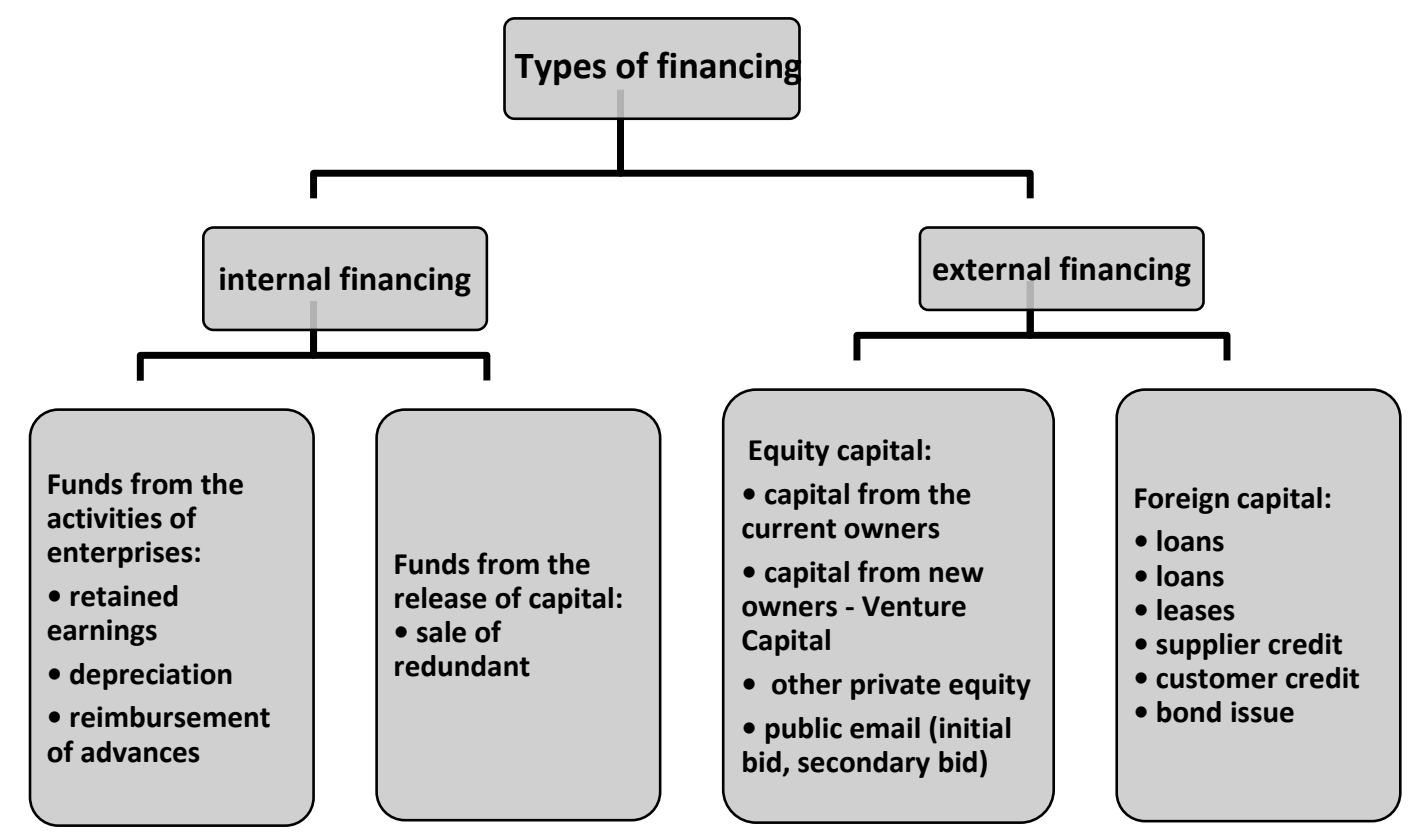

Figure 1. Types of enterprise financing according to the criterion of sources of capital acquisition

Source: Panfil, M. (2008). Finansowanie rozwoju przedsiębiorstwa z wykorzystaniem mezzanine. In: (ed. D. Zarzecki) Zarządzanie finansami - finansowanie małych i średnich przedsiębiorstw. Szczecin: Fundacja na Rzecz Uniwersytetu Szczecińskiego. 
Meeting the company's needs in the sphere of raising capital, related to both financing current and investment activities, involves using various forms of financing from the company's own or external sources. Determining the optimal structure of financing an enterprise is an extremely difficult task. When making decisions in this regard, management should take into account both the type of business and the degree of development of the company. Significant factors are also the costs and risks associated with a specific source of capital, as well as flexibility in adjusting the inflow of funds to the company's needs. Skillful management of the company's financing structure requires both extensive knowledge and experience on the part of management. It is also important to constantly observe new financial solutions which may better meet the needs of enterprises.

Although numerous studies of companies from the small and medium-sized enterprise sector indicate that these entities prefer internal sources of capital, such forms of financing often turn out to be far insufficient for further development of the enterprise.

Every enterprise needs appropriate financial resources to develop, invest, implement innovations, conduct market expansion and increase employment. In many cases, the funds held at the start, or generated in the course of a business activity, are not sufficient to implement the necessary investments and there is a need to look for external financing. At this point, many small and medium-sized companies face insurmountable barriers - high costs of entering the capital market (often much higher than in the case of large companies), the costs of bank loans, the lack of security or the lack of government guarantees (Szczepaniec, et. al., 2010, pp. 39-40).

\section{The capital gap is a barrier to the development of SMEs}

Small companies, often niche in terms of sector, often rely on limited resources. The concept of limited resources was taken from the resource and competence school (Obłój, 2007: 125-148), perceiving the organization as a set of resources and skills. In the case of small startups, material resources of a unique nature controlled by the enterprise play a key role. Intangible resources include assets such as reputation, brands, patents, as well as social and intellectual capital and relations with external companies. Another factor that characterizes small businesses is their limited financial resources (Poznańska, 2009, p. 195). Limited access of the small and medium-sized enterprise sector to capital is one of the significant barriers hindering the development of entrepreneurship in Poland and in the world (Skowronek-Mielczarek, 2013, p. 102).

The choice of an external financing source is determined by the experience, wealth and preferences of small and medium-sized entrepreneurs. In many cases, the need to raise capital is not fully satisfied with a bank loan. Difficult access to external sources of financing both owner and debt financing - is the result of high capital costs, complicated procedures of obtaining it or a low volume of equity.

The concept of an equity gap was defined by Harold Macmillan in the 1930s (Jóźwiak-Mijal, 2005, p. 49.). The classic definition assumes that the equity gap is the difference between the demand for capital reported for capital and its supply in the economy. It is a type of financial market failure resulting from information asymmetry between the enterprise and the provider of external capital. The equity gap is now also defined as a shortage of financial resources for the investment activity of a company, especially in the initial stages of development.

The existence of the financial gap in the Polish SME sector is confirmed by a number of market indicators, including in particular: a low percentage of companies using external financing, using capital from outside the financial market, and worse financing conditions for the SME sector. Although no high rates of credit refusals were recorded in the research conducted in Poland, situations of this type most often occur in the group of the smallest business entities. The fact that Polish small and medium-sized enterprises are undercapitalized may also be indirectly confirmed by relatively low (compared to other EU countries) indicators of innovation and internationalization. Research and development works, the implementation of new technologies and foreign expansion require large financial outlays. Deprived of easy access to external sources of financing and without other incentives conducive to development processes, Polish small and medium-sized companies will always have a worse competitive position, both on the domestic and foreign markets (Kulawczuk, Poszewiecki, 2010, p. 283.).

In response to the emerging gap in access to the capital necessary to finance the investments and operating activities of enterprises, newer and newer tools are created, aimed at reducing the size of the gap. These include, but are not limited to, government grants, sureties and guarantees, and other financial engineering instruments. The basis for decisions on the shaping of these 
instruments is the recognition of the SME sector as the engine of economic growth and the belief that the improvement in the availability of capital for small enterprises will directly translate into an increase in the number of jobs and GDP growth.

\section{Intervention financial support in response to the crisis caused by the COVID-19 pandemic}

The mechanism of economic recovery, after a period of slowdown caused by the epidemiological threat with the COVID-19 virus, will require specific actions by public authorities aimed at strengthening the investment activity of enterprises. Properly programmed support may become a factor that will positively influence the investment decisions of entrepreneurs.

In connection with the fight against the COVID-19 pandemic, the Polish government has proposed a package of protective measures for the economy, the so-called The Anti-Crisis Shield, which on March 31 this year was adopted by the Parliament of the Republic of Poland in the form of a special act. The shield is a comprehensive set of regulations counteracting the effects of the coronavirus on economic and social life. The shield contains a number of important solutions for financial support for companies, subsidies to jobs, exemptions from social security contributions, or the postponement of many administrative obligations. It is based on five pillars:

- protection of workplaces and employee safety,

- financing of entrepreneurs,

- health protection,

- strengthening the financial system,

- public investment.

One of the main elements of the so-called AntiCrisis Shield are protective solutions for employers and employees, which are supposed to allow companies to survive in the market and protect existing jobs. They are to reduce labor costs and enable the continuation of economic activity. Both small and large entrepreneurs who run a sole proprietorship and people employed under civil law contracts can count on support (Anti-Crisis Guide for Entrepreneurs, 2020).

As a part of the shield, the Polish Development Fund launched an aid program aimed at companies that suffered from the coronavirus pandemic. The program consists of three basic components with a total value of PLN 100 billion (4.5\% of GDP): PLN 25 billion will go to micro-enterprises, PLN 50 billion to small and medium-sized enterprises, and PLN 25 billion to large enterprises. Entities that will benefit from the program will receive a total of non-returnable funds worth PLN 60 billion. Firms in a difficult situation may take advantage of special solutions prepared by BGK in cooperation with ministries and the banking sector. The "Silesian package for the economy" is a proposal for entrepreneurs prepared by the Management Board of the Silesian voivodeship, which is a comprehensive offer of activities and real help for entrepreneurs, which was largely based on EU funds managed at the voivodeship level. The offer complements the government's activities under the so-called Anticrisis Shield. Due to the difficult situation in the economy of the region resulting from the current pandemic caused by the coronavirus and meeting the expectations of entrepreneurs, the Management Board of the Silesian voivodeship has developed a program that covers five pillars aimed at providing support to entrepreneurs. These five pillars include:

- working capital and liquidity loans along with other simplifications in the field of repayable support;

- supporting employers in maintaining jobs;

- non-repayable support, investment in smes and simplification for smes;

- self-government supporting activities;

- capital entries increasing the involvement of investors in the region.

\section{VC financing as an alternative to SMEs}

In addition to traditional sources of financing business activities, such as owner capitals, retained earnings, or loans and credits, there are also funds from investors willing to bear high risk. Here we are talking about Venture Capital (VC) (funds), i.e. private equity.

Polish terminology lacks an appropriate equivalent for the concept of venture capital, which is why the English nomenclature is commonly used. Often, however, to define this form of financing, the terms speculative capital, venture capital, VC funds, and capital involved in risky transactions are also used (Rossa, 2008). In Polish literature, the term Venture Capital is often replaced with private equity or venture capital. Private equity is a more general term, and it refers to all investments on the private capital market, carried out in order to achieve profits from the increase in the value of capita; and refers to investments at all stages of the company's development, including mature, well-established companies. By contrast, Venture Capital is used to refer to investments made in the early development stages of enterprises and concerns the start-up phase, early development and the initial stage of expansion (Panfil, 2005; Tamowicz, 2007). 
The first attempt to define Venture Capital was made by Georges Doriot (Spencer, 1992), who described the financing of ventures with certain features as:

- features of applying new technologies, new marketing concepts, new product application possibilities,

- significant, although not the most important, investors participation in the management of the company,

- investing in projects that employ people with the highest professional and moral qualifications in high positions,

- processes and products that have passed the early prototype stage and are adequately protected by patent law,

- projects that promise to mature enough within a few years in order to become the subject of a public offering or to an industry investor,

- non-financial investment opportunities in the form of improving the company's organization, management, etc. (Luciński, 2009, p. 461).

The Polish Association of Capital Investors defines Venture Capital as "investments in the private capital market, in order to achieve mediumand long-term profits from capital growth. Venture Capital can be used for the development of new products and technologies, increasing circulating capital, acquisitions of companies or improving and strengthening the company's balance sheet. Venture Capital is, in this approach, one of the types of private equity. Venture Capital private equity funds were created to finance investment projects which banks have looked askance of. These are high-risk investments, but they promise success, and so a high rate of return on capital.

Venture Capital is equity capital contributed for a limited period of time by external investors to small and medium-sized enterprises with a product, production method or service, which carry a considerable risk of failure; but at the same time, in the event of a successful investment supported by investors, ensure a significant increase in the value of invested capital, so generated by the selling of shares (Węcławski, 1997).

Venture Capital is considered as an alternative financing instrument for small and medium-sized enterprises - it corresponds to the specificity of financing innovative enterprises with high growth potential. From the point of view of novice entrepreneurs - inventors, capital support from funds is an attractive alternative to other sources of financing. First of all, at an early stage of development of an innovative enterprise, there are often difficulties with access to bank loans.
Venture capital is a type of investment in which the fund that invests the funds takes up shares in the company. This is often combined with supporting the company's operations (socalled smart money). Support from the Fund may consist, in particular, in consultancy and comanagement (especially at the strategic level), in assistance in recruiting experienced, highly qualified employees, in connecting the enterprise to the fund's network of contacts (e.g. with suppliers, cooperators, clients), in legal services and the field of public relations. The benefits for companies of cooperation with Venture Capital funds cannot be overestimated. Cooperation with a fund that has a good team and wants to consistently build its market value together with the owners of the company, jointly refine the development strategy, optimize the business model and organizational structure, mobilize to keep costs in check, acting on the basis of goals, or stimulate the implementation an information policy that helps build market credibility and attractiveness.

Currently, about 100 VC / PE funds operate on the Polish market. Venture capital is used by a small group of small and medium-sized enterprises - the importance of these funds on a national scale is marginal. The reasons for this lie both with the small and medium-sized enterprises and with the funds. It has proved difficult for small and medium-sized enterprises to meet the requirements of the funds, and business owners are also afraid of losing full control over the company. Funds, on the other hand, are choosing to avoid high investment risk, focusing more and more often on investments in companies with an established position on the market. VC funds mainly invest in those small and medium-sized enterprises that have a good product, have been successful in the market, but lack capital for further development. Investments in the early stages of enterprise development are rather rare (Wolański, 2013, p. 153)

The biggest barrier to the development of small technological companies is insufficient capital equipment, due to the low levels of tangible assets that enable the securing of banking transactions, the short period of operation making it impossible to determine the financial standing based on the bank rating, as well as the specificity of the industry, often in the area of new technologies, a barrier for commercial banks due to the high level of transaction risk. Such enterprises, in the face of the policy of commercial banks, and in the face of the economic crisis caused by the coronavirus pandemic, remain without access to working capital and investment capital for development. The crisis and economic 
slowdown have severely limited access to loans or other debt instruments for many companies. It is precisely due to the low availability of loans and relatively high costs of obtaining share capital, as well as aforementioned substantive support, that Venture Capital is considered a very good source of funding, especially for small, innovative enterprises. Due to low risk aversion and providing additional non-financial support (in management, in establishing business contacts), funds are a particularly valuable partner for innovative enterprises at certain stages of their development. One of the most important benefits of Venture Capital is the possibility of implementing even very risky projects without appropriate security, which, for example, could be required by a bank. Oftentimes, this is the only way to implement a high-risk project already in the product, service or business setting up phase. This is especially important when the founders and their immediate environment do not have the appropriate funds. The nature of the capital employed is also one of the advantages of venture capital. In the case of a venture fund, the obtained funds increase the company's share capital. This means that the company is not obliged to repay the granted financing, and additionally it is not charged with any financial costs. Therefore, the change in the balance sheet structure does not adversely affect the company's financial capacity to incur further liabilities (Szczepaniec, et al., 2010, p. 65).

The activity of Venture Capital funds has been described in many scientific works. However, they were not presented in the context of the wide impact on the economy affected by the recession, as well as their impact on small companies, often including niche ones, which faced the need to make strategic decisions whether to start or continue development projects based on new technologies in the event that a challenge is the company's daily liquidity. As a rule, when analyzing the functioning of Venture Capital funds, reference is made to the analysis of added value for the capital market, and rarely in the context of value for the clients of their portfolio companies in the context of building customer satisfaction and loyalty generated due to the investment of products and services provided by them. The document emphasizes the separate nature of the value built in the professional activities of Venture Capital funds, especially with regard to the need to redefine investment policies and development strategies in a situation where new technology sectors have also undergone significant changes caused by the COVID-19 pandemic. The influence of these factors and their influence have been analyzed only in a few scientific works, usually fragmentarily; therefore the characterization of this type of processes is of great cognitive importance. Few works describe the functioning of funds in relation to small companies and it is worth noting that there are over 1.7 million of them in Poland, and the majority of them develop on the basis of niche activities. Venture Capital funds are becoming a tool for counteracting the crisis in the most critical section, which is small entrepreneurship in every edition, regardless of the stage of development, from the pre-seed, seed, early stage, expansion or late stage levels in the nomenclature of VC funds. The analysis in this economic environment seems justified. The essence, functioning, role of funds in the economy, and most importantly, everyday work described by a practitioner who deals with capital investments on a daily basis. However, the methods of building the business relationship and value of funds and small niche companies are poorly understood, the management methods used by the managers of such enterprises in value chains have not been described.

\section{Silesian Development Fund (Śląski Fundusz Rozwoju (ŚRR) - analysis of the perception of capital entries in the context of available financial instruments. Conclusions from the research}

The Silesian Development Fund is a specialized regional financial institution, the aim of which is to build in Silesia a sustainable long-term financing system for micro, small and medium-sized enterprises and local government units in the region. In practice, the company's task is to organize support programs for Silesian companies based on repayable financial instruments, i.e. loans, guarantees, sureties, equity instruments, as well as sureties for loans, leases, factoring and bid bonds. The mission here is to support innovative and rapidly developing companies from the region of Silesia, belonging to the sector of micro, small and medium-sized enterprises. As a part of the task carried out by SDF Silesian entrepreneurs will have at their disposal modern financial products tailored to the smart specializations of the voivodeship. SFR creates financial instruments aimed at investing in knowledge and technologies in cooperation with financial institutions and financial brokers. The target group and recipients of ŚR financial products are companies from the micro, small and medium-sized enterprises sector. The flagship product of the SDF is the investor instrument - Capital Entry, which is intended to finance innovative and development projects carried out in the Silesian voivodeship by existing companies or startups. In order to increase investment opportunities as well as reduce risk, 
the Silesian Development Fund attracts coinvestors to conduct investments. Capital Entries are also one of the five pillars of the Silesian Package for the Economy - a comprehensive program of recovery from the recession caused by the pandemic. Recruitment under the instrument was launched on April 20, 2020 and is conducted on an ongoing basis.

\section{Research methodology}

Due to the fact of launching recruitment under the investment instrument Capital Entry, the Management Board of ŚFR decided to conduct an evaluation study of the level of customer satisfaction and its needs in terms of the availability of capital for the development of innovative projects. The research covered all Project Initiators who registered on the dedicated platform. To date (30.06.2020), 100 individual project accounts have been created on the platform. The total sample size was $\mathrm{N}=35$. The survey was conducted in the period 18.05.2020 19.06.2020 via email. The offer under the "Entrance Capital" investment facility was addressed to micro, small and medium-sized enterprises.

Most of the project initiators included in the survey are companies operating on the market for over a year $(76 \%)$. Only $8 \%$ of the respondents are in the seed and pre-seed stages.

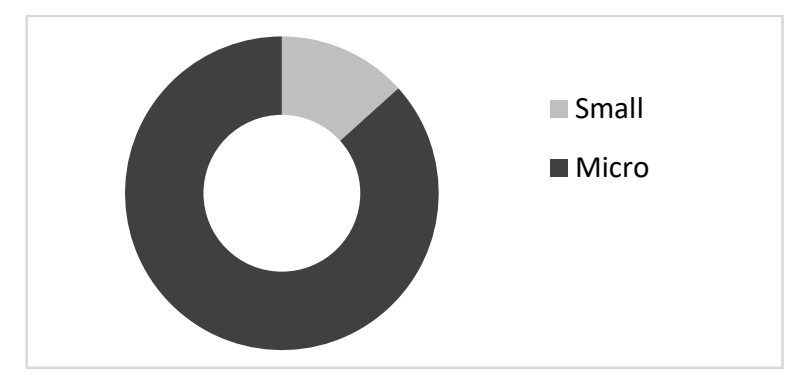

Figure 2. Structure of respondents by enterprise size Source: own study.

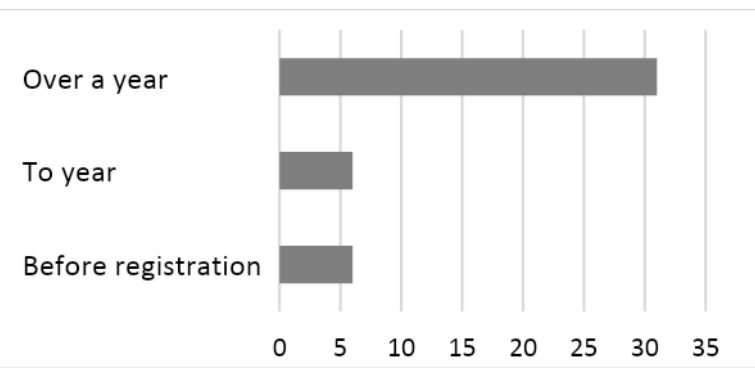

Figure 3. Structure of respondents according to the period of running a business Source: own study.
Most of the companies covered by the study come from the ICT area. The respondents also hailed from companies from the medical technology, biotechnology, industrial and automotive sectors.
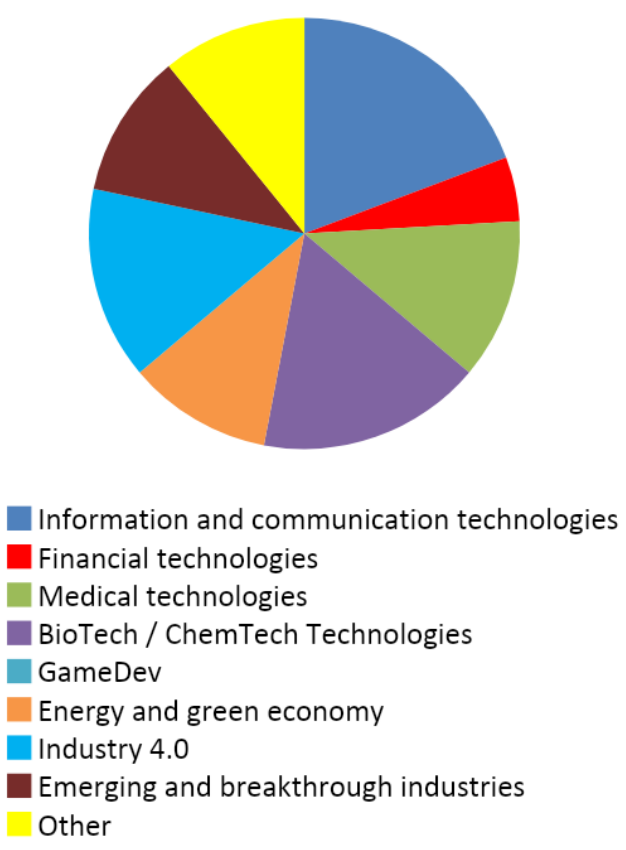

Figure 4. Structure of respondents according to the activity sectors

Source: own study.

\section{Research findings}

The vast majority of respondents considered access to financing sources to be difficult. Over $60 \%$ of respondents, when asked about access to sources of financing for projects, replied that it was difficult, and almost 3\% that it was impossible.

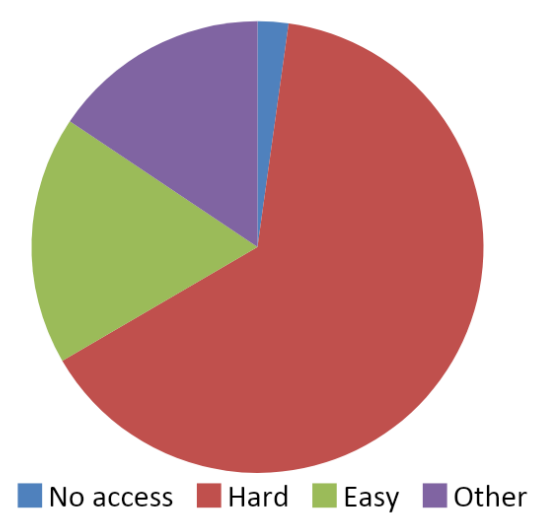

Figure 5. Assessment of access to investment capital by respondents Source: own study. 
When asked about the project financing model, the vast majority of respondents indicated equity as the primary source of financing $(74.3 \%)$. The survey shows that respondents are much more likely to reach for capital from VC funds $(37.1 \%)$ than debt capital in the form of credits or loans $(5.7 \%)$.

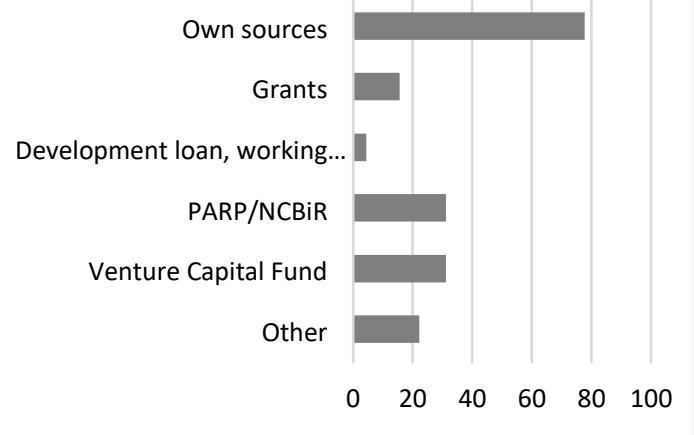

Figure 6. Assessment of the project financing model by the respondents

Source: own study.

The questioners referred in a similar way to the attractiveness of individual financial products available on the market. The respondents considered private equity and Venture Capital as the most attractive due to the additional value of these instruments in the form of smart money.

Interestingly, the majority of respondents positively assessed the attitude of financial institutions offering various instruments to support entrepreneurship. Less than $3 \%$ of the respondents clearly negatively assessed the attitude of institutions offering financial products.

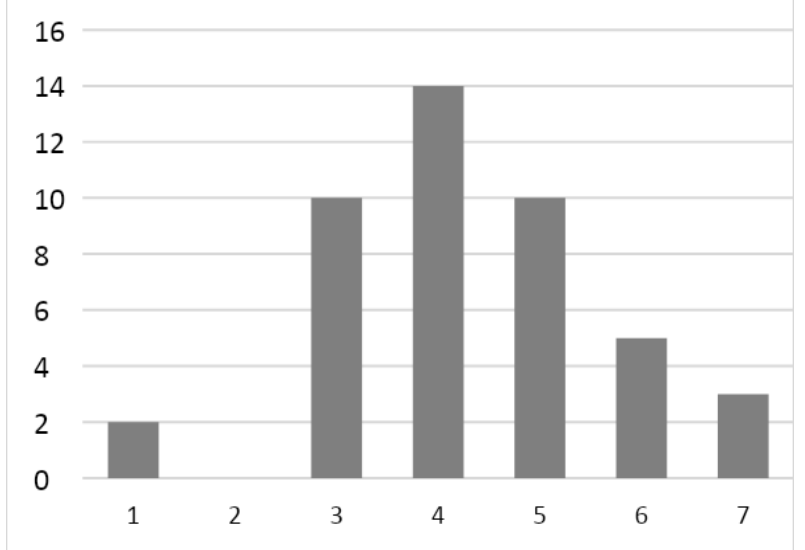

Figure 7. Assessment of financial institutions by the respondents

Source: own study.

\section{Conclusions}

No crisis lasts forever. History shows that every economic boom has its end. There is one word in Chinese that means both threat and opportunity. This paradox has its justification. Oftentimes, crisis situations force us to make bold decisions that were not taken into account in times of prosperity. Most companies will be more or less affected by the COVID-19 crisis. Not enough, however, to disappear from the market. Some industries will be hard hit, whereas others will thrive.

For many companies, especially micro and small entities, in the time of the COVID-19 pandemic, it has been essential to maintain liquidity, including the ongoing, systematic regulation of fiscal and employee burdens, which will ultimately help avoid job cuts and bankruptcy. At present, the boards of Polish companies seem to be thinking primarily about cost reduction and restructuring measures.

At the same time, it should be remembered that the time of crisis is the time of the greatest investment opportunities. The management boards of Polish enterprises are increasingly beginning to be cognizant of the advantages of cooperation with private equity funds investing in private assets. The slowdown in the Polish economy caused by the crisis caused by the pandemic and the related difficulties of companies with obtaining capital through public issuance of securities may make financial investors an attractive source of capital, financing the developmental needs of enterprises.

The mechanisms for an economic turnaround will entail specific impulses, such as entrepreneurship, understood as the tendency of entrepreneurs to seek innovative solutions, change, optimize or even create new production abilities. This requires specific investment activities.

It is obvious that in the current epidemiological situation, making a decision to invest requires specific sources of financing. The end of the epidemic may mean a "new start" for many companies, bringing new opportunities for development. However, this will mean an increased demand for money, the availability of which on the financial market will be strongly limited due to the restrictive policy of traditional financial institutions. In a situation of limited access to loans and other debt instruments, one of the most effective ways to raise capital for development will entail cooperation with VC funds. Although Venture Capital funds are not very important in generating employment or managing capital, the role they play in the economy should not be underestimated. When considering the role, 
it should be kept in mind that many of the leading US technology companies started their operations with the support of VC funds. In addition, VC supported investments are seen as particularly prominent in the innovation process.

It is hoped that the negative experiences of the epidemic will become a positive factor, enabling an economic recovery and contributing to the innovative development of the Polish economy in the coming years; particularly pertaining to production ability through those investment processes financed by entrepreneurs; and supported by public institutions and Venture Capital funds.

\section{References}

Anti-crisis Guide for Entrepreneurs, Polish Development Fund, May 2020.

Czerniak, J. (2010). Fundusze Venture Capital jako źródło finansowania innowacji (Venture Capital Funds as a source of financing innovation). Annals of the Marie Curie Curie-Skłodowska University in Lublin, XLIV (2), 811-820.

Derkacz, A., (2020). Pierwotne źródła ożywiania gospodarki po spowolnieniu epidemiologicznym. Czy M. Kalecki dat receptę na poprawę koniunktury gospodarczej $w$ dobie globalnej epidemii wirusa COVID-19? [Primary sources of economic recovery after the epidemiological slowdown. Did M. Kalecki give a prescription for improving the economic situation in this era of the global COVID-19 virus epidemic?]. Bydgoszcz: Polish Economic Society.

Jóźwiak-Mijal, M. (2005). Luka Macmillana a znaczenie średnich przedsiębiorstw dla gospodarki [The Macmillan Gap and the importance of medium -sized enterprises for the economy], Studia i Materiały Wydziału Zarządzania UW (1), 49-53.

Luciński, W. (2009). Zakresy pojęciowe private equity $i$ Venture Capital $w$ tradycji amerykańskiej $i$ europejskiej. (Concepts of scope. Private equity and venture capital in the American and European tradition). Zeszyty Naukowe Uniwersytetu Szczecińskiego. Finanse, Rynki Finansowe, Ubezpieczenia, (16), 461-472.

Panfil, M. (2008). Finansowanie rozwoju przedsiębiorstwa $z$ wykorzystaniem mezzanine [Financing of enterprise development with the use of mezzanine]. In: (ed. D. Zarzecki) Zarządzanie finansami - finansowanie małych $i$ średnich przedsiębiorstw (Financial management - financing of small and medium enterprises). Szczecin: Fundacja na Rzecz Uniwersytetu Szczecińskiego.
Panfil, M. (2005). Fundusze private equity. Wpływ na wartość spółki (Private Equity funds. The impact of company valuation). Warsaw: Difin.

Prędkiewicz, K. (2013). Granice luki kapitałowej w Polsce. Zeszyty Naukowe Uniwersytetu Ekonomicznego w Krakowie (The limits of the equity gap] Scientific Journals of the University of Economics in Cracow, (901), 129-143.

Rosa, A. (2009). Alternatywne instrumenty finansowania (Alternative financial instruments). In: (eds. A. Bielawska) Nowoczesne zarządzanie finansami przedsiębiorstwa (Modern financial management for enterprises). Warsaw: C.H. Beck.

Rossa, A. (2008). Venture Capital w Polsce, Zeszyty Naukowe Wydziału Nauk Ekonomicznych Politechniki Koszalińskiej (Venture Capital in Poland, Scientific Journals of the Institute of Economics and Management of the Koszalin University of Technology, (12), 133-143.

Skowronek-Mielczarek, A. (2002). Źródła zewnętrznego finansowania małych $i$ średnich przedsiębiorstw w Polsce [The external sources of financing small and medium-sized enterprises in Poland], Monografie i Opracowania 499. Warsaw: SGH, 2002.

Szczepaniec, M., Babula, E., Poszewiecki, A., Zaucha, J., Kulawczuk, P., Jurkiewicz, T. (2010). Behawioralne oddziaływanie framing na skłonność do korzystania $z$ instrumentów finansowych przez małe $i$ średnie przedsiębiorstwa [Behavioral determinants of framing on the tendency to use financial instruments by small and medium-sized enterprises]. In: (ed. P. Kulawczuk, A. Poszewiecki) Behawioralne determinanty rozwoju przedsiębiorczości w Polsce. Ekonomia behawioralna finansowania przedsiębiorczości [Behavioural determinants for the development of enterprises in Poland. The Economic Behaviour of Financial Enterprises]. Gdańsk: Fundacja Rozwoju Uniwersytetu Gdańskiego.

Tamowicz, P. (2007). Business Angels. Pomocna dłoń kapitału (Capital as a helping hand). Warsaw: Polska Agencja Rozwoju Przedsiębiorczości.

Tamowicz, P., Rot, P. (2002). Venture Capital Funds in Poland: Warsaw: Polish Foundation for Enterprise Development.

Węcławski, J. (1997). Venture capital. Nowy instrument finansowania przedsiębiorstw (New financial instruments for firms). Warsaw: PWN, 1997.

Wolański, R. (2013). Wpływ otoczenia finansowego na konkurencyjność małych i średnich przedsiębiorstw (The financial environment and competition for SMEs). Warsaw: Wolters Kluwer Polska. 